\title{
Michał Rogalski, Producenci margaryny? Marian Zdziechowski i pol- ski modernizm katolicki, Kraków 2018, ss. 245
}

W Polsce do dziś można spotkać się z silnym połączeniem identyfikacji narodowej z religijną. Ów stereotyp przyczynia się do rozpowszechnienia przekonania, jakoby polska wspólnota narodowa w zdecydowanej większości składała się z ortodoksyjnych katolików. Niemniej historia zna myślicieli, którzy - wywodząc się z katolickiej tradycji religijnej - kwestionowali jej istotne składniki, jednak bez odchodzenia w całości od katolicyzmu. Przykładem takiego ruchu był tak zwany modernizm (nie mylić z prądem w sztukach o tej samej nazwie), rozwijający się na przełomie XIX i XX wieku równolegle $\mathrm{z}$ podobnymi ideami na Zachodzie i potępiony przez Piusa X w encyklice Pascendi Dominici Gregis (1907 r.). To właśnie dzieje i dorobek ideowy polskiego modernizmu stanowią temat książki Producenci Margaryny? Marian Zdziechowski i polski modernizm katolicki.

Owa publikacja stanowi jedynie szkic (s. 216). Zważywszy jednak na niepopularność tej tematyki w dotychczasowej literaturze, nie stanowi to wady. Autor podjął się zadania pionierskiego. Praca ma klarowną strukturę, składa się z trzech głównych części. W pierwszej naszkicowano, zarysowano problematykę myśli modernistycznej - wyróżniono tu historyczność, dogmaty, jednostkę i wielość (pod tym pojęciem autor rozumie swego rodzaju relatywizm) - z zastrzeżeniem jednak, że modernizm nie był jednorodnym ruchem. Drugą część pracy poświęcono Marianowi Zdziechowskiemu, którego uznano za najistotniejszego polskiego modernistę. Opisane są początki jego związków z myślą modernistyczną, rozwój koncepcji oraz faza schyłkowa. Trzecią część pracy wypełniają krótkie szkice dotyczące głównych założeń polskiego antymodernizmu oraz idei innych myślicieli modernistycznych. Całość wieńczy próba syntetycznego ujęcia modernizmu oraz jego oceny. W przekonujący sposób autor uzasadnił wybór Zdziechowskiego na głównego bohatera swojej pracy - Zdziechowski posiada największy dorobek pisarski związany z modernizmem i jako jedyny z polskich modernistów wszedł w międzynarodowy obieg idei (s. 13). Trafnie oddzielono od obszaru zainteresowań pracy kwestię antymodernizmu, który ze względu na swoistość domaga się oddzielnego opracowania (s. 15).

Autor wykorzystał przy swoich badaniach różnoraką bazę źródłową. Nie tylko zapoznał się z licznymi tekstami publicystycznymi i naukowymi autorstwa polskich modernistów, ale także z ich spuścizną związaną z życiem prywatnym, na przykład z zachowaną w archiwach korespondencją Zdziechowskiego.

Istotną zaletą pracy jest wyraziste przezwyciężenie koncepcji forsowanej przez propagandę antymodernistyczną, jakoby modernizm na ziemiach polskich miał być 
nieobecny. Autor zwraca uwagę, że owa opinia to raczej chwyt propagandowy czy zaklinanie niż odzwierciedlenie realiów. Teksty antymodernistyczne często były oderwane od rzeczywistości i atakowały wroga, którego opis odpowiadał bardziej wyobrażeniom antymodernistów, niż faktom (s. 145-151, 219).

Na plus zaliczyć też należy część pracy poświęconą myśli Zdziechowskiego. Także i ona ma charakter wstępnego rozpoznania, nieraz w dużej ogólności, lecz pozwala zorientować się, na podstawowym poziomie, w najważniejszych pracach tego filozofa.

Autor podjął się również zadania zwięzłego przedstawienia nie tylko oryginalnych polskich tekstów, ale i tłumaczeń tekstów modernistów obcojęzycznych na język polski (s. 152-155). Pozwala to szerzej i pełniej spojrzeć na polski fenomen myśli modernistycznej i jego funkcjonowanie w polskojęzycznym obiegu literackim. Oprócz tego należy docenić próby periodyzacji dziejów modernizmu, przyjmując za punkt wyjścia publikację Pascendi Dominici Gregis (s. 158-159).

Niestety nie udało się uniknąć dość poważnych mankamentów. Pierwszy to wadliwe zdefiniowanie samego modernizmu - pojęcia kluczowego dla całej książki. Według słów autora można postawić znak równości między dążeniami do reform w obrębie katolicyzmu a modernizmem (s. 10, 26, 209, 215). Tak szeroka definicja wynika zapewne ze słusznego przekonania o niejednorodności tego ruchu. Jako narzędzie badawcze jest jednak wadliwa (zbyt szeroka) i nie odzwierciedla stanu faktycznego. Przy konsekwentnym przyjęciu takiej definicji należałoby uznać za modernistów wiele osób, które z tym nurtem nie miały wiele wspólnego, na przykład Honorata Koźmińskiego, niezwykle aktywnego reformatora życia zakonnego na terenach zaboru rosyjskiego ${ }^{1}$, czy też papieża Leona XIII, który przyjmował pojednawczą postawę względem zyskujących popularność liberalnych (jak na ówczesne standardy) prądów politycznych, na przykład w encyklikach Diuturnum Illud czy też Graves et Communi. Stosowniejszą definicją byłoby więc uznanie modernizmu za te prądy szeroko pojętego liberalizmu w katolicyzmie przełomu XIX i XX wieku, które w swoich postulatach wykraczały poza dogmatyczne ramy katolicyzmu.

Drugim, istotnym defektem jest pojmowanie przez autora pojęcia cywilizacji oraz koncepcji pojednania między Kościołem katolickim a tą cywilizacją. Ów termin nie jest na stronach książki precyzyjnie zdefiniowany. Na podstawie fragmentów, w których pojawia się to pojęcie i pojednania z cywilizacją (s. 26, 29, 55, 68, 75, 91, 209, 215-217) można wnioskować, że przez cywilizację autor rozumie jakieś prądy intelektualne istniejące w wąskich kręgach kultury elitarnej, które kontestowały katolicyzm oraz pewne (jakie konkretnie - niełatwo stwierdzić) laicyzacyjne trendy w polityce niektórych państw europejskich². Trudno powiedzieć, jakie idee

${ }^{1}$ Por. B. Szewczul, Działalność zakonodawcza błogostawionego Honorata Koźmińskiego a nowe instytuty w Kościele katolickim. Studium prawno-historyczne, Warszawa 2008, s. 65-93, 256-288.

2 „Modernizm katolicki jest wielonurtowym ruchem, dla którego wspólną płaszczyznę stanowi przekonanie o konieczności zbliżenia czy pogodzenia katolicyzmu przełomu wieków XIX i XX ze współczesną cywilizacją [...]. Chodzi o unowocześnienie katolicyzmu: wprowadzenie do myślenia katolickiego pojęć, szkół, metod wypracowanych przez najnowsze badania naukowe i filozoficzne oraz poszukiwania artystyczne" (s. 26). 
autor ma dokładnie na myśli - brak tu precyzyjnego dookreślenia. Poprzez tak elitarystyczne ujęcie cywilizacji katolicyzm jest pojmowany bardzo wąsko - nie jako szeroki fenomen społeczny, a właśnie system filozoficzny dla dywagacji elit. Daje to bardzo wykrzywiony obraz zagadnienia. Pojednanie z tak nieprecyzyjnie rozumianą cywilizacją uznaje on za warunek przetrwania Kościoła na przełomie XIX i XX wie$\mathrm{ku}$. O ile $\mathrm{z}$ tezą o istotności dialogu $\mathrm{z}$ tak wąsko pojmowaną cywilizacją $\mathrm{w}$ myśli modernistycznej należy się zgodzić, o tyle uznawanie jej za kluczowy problem dla ówczesnego Kościoła jest wprost niezgodne z faktami. Jak wskazał chociażby Daniel Olszewski w książce Kultura i życie religijne spoleczeństwa polskiego w XIX wieku (którą uwzględniono w bibliografii recenzowanej pracy!), realne problemy stojące przed katolicyzmem były wówczas zupełnie inne. Wiązały się z zapewnieniem opieki duszpasterskiej w miastach oraz budzeniem się świadomości klasowej chłopów i robotników ${ }^{3}$. Osoby interesujące się modernizmem stanowiły ułamek procenta społeczeństwa i nie mogły przesądzać o losach Kościoła. Poza tym pozostaje kwestia, czy modernizm w praktyce (a nie tylko w autodeklaracji) mógł być rzetelną odpowiedzią dla „cywilizacji”. Tego pytania nie postawiono w recenzowanej pracy.

Problemem jest też brak choćby hipotetycznego zarysowania skali recepcji i zainteresowania modernizmem w polskim społeczeństwie. Autor formułuje tezę, że modernizm nie był w kulturze polskiej zjawiskiem marginalnym (s. 12, 122, 216), nie przedstawia jednak dostatecznej argumentacji na jej poparcie. Zdaje się więc, że znacząco tutaj przeceniono dziejową doniosłość modernizmu.

Problematyczny jest też pogląd, że modernizm nie naruszał katolickich zasad wiary (s. 39-42, 131). W istocie moderniści niejednokrotnie występowali przeciw podstawowym tezom katolicyzmu (co widać wyraźnie w rozdziale Podstawowe problemy modernizmu katolickiego). Padają także błędne sugestie, że wiele z kluczowych idei modernistycznych zostało ostatecznie inkorporowanych do katolicyzmu w okresie Soboru Watykańskiego II (s. 220). Wspominana zaś przez autora przysięga antymodernistyczna (s. 219) do dziś może być składana dobrowolnie i stanowi element magisterium, zniesiono jedynie obligatoryjność takiego ślubowania dla seminarzystów ${ }^{4}$.

Wyraźne sympatyzowanie autora z modernistami zniekształca jego pogląd na osoby spoza tego środowiska. Na przykład encyklika Libertas Leona XIII została streszczona w formie odbiegającej od pojednawczych intencji jej twórcy (s. 67), a encyklika Pascendi Dominici Gregis jest uznawana za złą bez wyłożenia argumentów (s. 37). Wywód jednocześnie często podąża dość bezwiednie za myślą Zdziechowskiego i nie poddaje krytycznemu rozbiorowi na przykład nieoczywistego interpretowania pism Johna Newmana (s. 124). Książka w ten sposób przemienia się $\mathrm{z}$ rozprawy naukowej w niewyważoną apologię modernistów.

Należy jednak wyrazić uznanie dla autora, że zdecydował się podjąć pionierską pracę w dziedzinie dotychczas zaniedbanej. Publikacja trafnie zarysowuje niektóre

${ }^{3}$ D. Olszewski, Kultura i życie religijne społeczeństwa polskiego w XIX wieku, Lublin 2014, s. $379-425$.

${ }^{4}$ „The oath against modernism” [b.a.], Dowry. An English Periodical of Catholic Tradition by Priestly Fraternity of Saint Peter 2012, nr 15, s. 5. 
z głównych idei modernizmu, sylwetki jego polskich myślicieli, jak i swoistość antymodernizmu. Niestety jednak istotne mankamenty warsztatu, związane także z kluczowymi terminami i osadzaniem modernizmu w realiach epoki, poważnie obniżają walory naukowe książki. Tak jak retoryka antymodernistyczna na długie lata zniekształciła pojmowanie zjawiska modernizmu, tak przyjęte stanowisko, wyraźnie przychylne modernizmowi, nie daje czytelnikowi zrównoważonego i rzetelnego obrazu tego fenomenu.

Łukasz Kożuchowski id http://orcid.org/0000-0001-5774-2898

Uniwersytet Warszawski Adres do korespondencji: lukaszkozuchowski1@gmail.com 